\title{
Designing Emission from the Point of View of Geometric Parameters of the Emitter
}

\author{
Monika Wierzbińska ${ }^{1}$ \\ 1 Institute of Environmental Protection and Engineering, University of Bielsko-Biała, ul. Willowa 2, 43-300 \\ Bielsko-Biała, Poland, e-mail: mwierzbinska@ath.bielsko.pl
}

\begin{abstract}
The paper presents the calculation results of the concentration of particles suspended in the air, taking into account various geometric parameters of the emitter and especially its height and diameter on the given examples. The situations where the emitted pollution comes from low emitters characteristic for single-family households, and then also from emitters of industrial type as well as high chimney stacks characteristic for thermal power plants were considered. For the cases mentioned above, modelling of the geometric parameters of an open point source was performed. The visualisation of results, presented in isoline maps of PM10 dust concentrations, has enabled to conduct an analysis of differences in immission and dispersion of the particles suspended in the air within the diameter ten times larger than the height of the point source/emitter.
\end{abstract}

Keywords: emission designing, pollution dispersion, emitter/point source, Pasquill model

\section{INTRODUCTION}

One of the methods to protect the air and to limit immission of pollution in the air is a wise and a well-thought-out designing of emitters which will participate in the process of introducing pollution to the atmosphere: from households, industrial plants, boiler houses, and from the power industry. One of the tools used for modelling and monitoring the immission of pollution in the air and enabling us to make a comprehensive analysis of air quality within emitters' range is the Ek100w programme by Atmoterm. The software enables to perform calculations of pollution concentration in the area on the basis of the Polish Pasquill model, as a reference method to calculate the influence of emission from point sources into the ambient air.

\section{Factors determining the distribution of air pollution immission}

Designing the emission of pollutants consists in modelling the parameters and analysing the distribution of concentration (immission) of pollution emitted in the area within various distances from the emitters. This parameters are related to meteorological conditions e.g. wind, temperature of the air, height of the inversion layer, related to topographic profile and height, diameter of the emitter or temperature of waste gases [1].

Pursuant to the Act of 27 April 2001, Environmental Protection Law, emission is direct or indirect introduction of pollution into the environment. It is caused by a human activity [2]. Immission is a measure of the degree of pollution, defined as a concentration of pollutants in the air, expressed in the mass units of the given pollutant per unit of air volume: $\mu \mathrm{g} / \mathrm{m}^{3}$ or $\mathrm{ppm}$, $\mathrm{ppb}$. The evaluation of the level of substances in the air is made by comparing them with the permissible concentration values of the substances in the air [3].

The movement of gas and solid pollutants in large masses of ambient air is called atmospheric dispersion of pollution. As a result of the dispersion of pollution, a time and space change occurs in the condition and quality of the atmosphere. Dispersion of pollution in the vicinity of the sources of their emission leads to an increase 
of immission, i.e. an increase in the concentration of polluting substances in the surrounding air. While moving in the air, the flume of pollution leaving the emitter undergoes complex processes and changes which are significantly influenced by the topographic and meteorological factors as well as the geometric parameters of the emitters themselves [4].

The article analyses the influence of the geometric parameters, especially the height and diameter of the emitter, on the atmospheric dispersion of pollution. Such analyses allow us to optimize the parameters while designing emission.

The waste gases introduced to the ambient air via chimneys are subject to the phenomenon of "plume rise" $\Delta h$ (Figure 1). The plume rise is created as a result of the use of kinetic energy and the uplift pressure of the gas sent to the atmosphere and it is determined by the outlet velocity of the gases $-v$. The waste gases mix with the surrounding air moving at a speed $-u$. Thus, the gasses emitted from chimneys give an impression that they are emitted higher than from the geometrical height of the chimney - this height is called the "effective emitter height" $-\mathrm{H}$ and determines the distance of the exhaust trail axis from the surface of the Earth.

The movement of the plume of emitted gasses may be divided into three phases which are characterised by the plume (exhaust trail) axis, the section area and the density of the plume, by the temperature of the gases, and by the concentration of pollution $[2,8]$.

\section{Methodology of pollution emission designing by modelling the geometric parameters of a point source (emitter)}

The analysis of atmospheric dispersion of pollution was carried out by calculating the concentration of the PM10 suspended dust in the air at various distances from the emitter. The Ek100w programme by Atmoterm company was used as a tool, which enabled to graphically present the results in the form of isolines on maps. The software is based on the Pasquill's model. This model is especially recommended by the Ministry of Environment [5]

The Pasquill's equation is a solution to the reduced differential equation of the diffusion of pollution in a moving gas medium. The solution to the Pasquill's equation is the concentration of pollution in every point of the calculation area. Due to numerous simplifications used in the formula, the following, among others, are not taken into account: the absorption of the plume by the ground, chemical changes of the pollution, or the phenomenon of gravity settling [6]. The correctness of the result from the model of pollution dispersion with the use of the Pasquill formula depends on the influence of the atmosphere condition as well as the meteorological and topographic factors of the area $[4,6]$.

The Ek100w programme by Atmoterm S.A. is a tool allowing us to conduct an analysis of the dispersion of pollution in ambient air, emitted from different shape emitters [7-10].
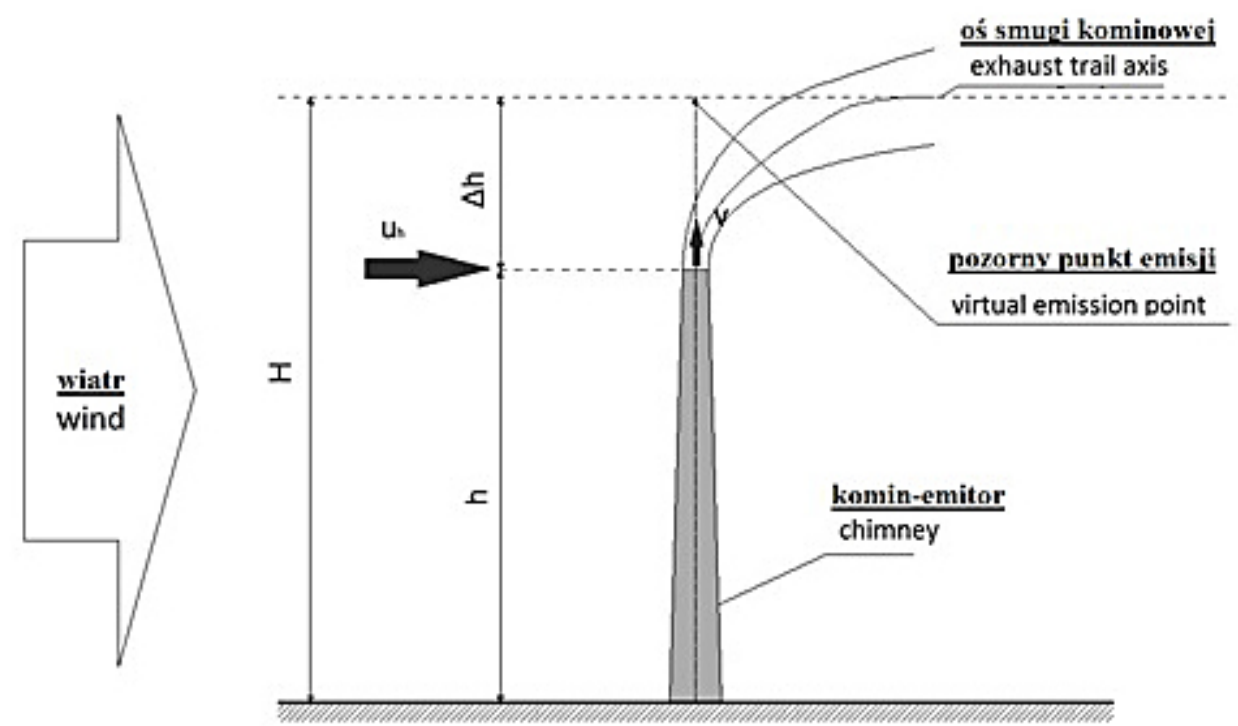

Figure 1. Diagram of plume movement [1] 
The calculation methodology is based on the methodology of modelling defined in the Order of the Minister of Environment of $26^{\text {th }}$ January 2010 concerning the reference values for particular substances in the air [5].

The calculations were performed for the parameters presented in Table 1 and 2. It was assumed that the emitter is an open point source (emitter) with the height of $h$ and an internal diameter of $d$. The parameters which were subject to the modelling were the height and the internal diameter of the emitter. Thus, one emitter was used for the calculations with variable parameters determined for various cases shown in Table 2 . The situations where the emission came from an average household, from a 4- and 10-metre high emitter, then from a small production/industrial plant with a 1- and a 50-metre high emitter, and from a 90- and 110-metre high chimney stack at a thermal power plant were analysed. The abovementioned cases were also analysed from the point of view of emission and the differences of immission for various diameters of the analysed emitters. The values of emission and velocity of the exhaust at outlet from the emitter were assumed as the actual average for the individual emission situations (Table 2).

The obtained results, in the form of dust concentration tabulation in all points of the calculation net, were visualised in isoline maps of concentration in the calculating area of a diameter equal to $50 \mathrm{x} \mathrm{h}$. Then, an analysis of the isoline layout changes was conducted in the cases where changed data was used for the same parameters. An analysis was carried out for the aerodynamic surface roughness coefficient, characteristic for areas covered with dense rural land development or low land development of small and large towns being $\mathrm{z}_{0}=0.5 \mathrm{~m}$. Average annual ambient temperature of $8^{\circ} \mathrm{C}$ and the gas temperature at the emitter outlet of approx. $400 \mathrm{~K}$ were assumed for the calculations. The emission time was 8600 hours in a year. The calculation nets were assumed at the height of $0 \mathrm{~m}$ (Table 1).

\section{RESULTS}

Entering the data to the Ek100w programme enabled to calculate the PM10 dust concentrations in the air within the diameter of fifty times the height of the emitter $(50 \times \mathrm{h}$ ). The results were visualised in the form of isolines of concentration on maps presented in Figure 2-11. The areas, where the immission was highest (up to approx. $10 \times \mathrm{h}$ ) were shown in the maps, i.e. not all the maps presented here show the total calculation areas. The emitter was marked on the maps with a black dot and "E" symbol.

Figure 2 and 3 depict the way of PM10 dust dispersion in the atmosphere emitted by an emitter characteristic for a single-family household, with a variable height $-\mathrm{h}-$ of $4 \mathrm{~m}$ and $10 \mathrm{~m}$.

Figures 4 and 5 present the way of chimney flume distribution from the same emitter at

Table 1. Common parameters of analysed cases

\begin{tabular}{|l|c|c|}
\hline \multicolumn{1}{|c|}{ Parameter } & Unit & $\begin{array}{c}\text { Introduced } \\
\text { value }\end{array}$ \\
\hline Average ambient temperature & {$\left[{ }^{\circ} \mathrm{C}\right]$} & 8 \\
\hline Emission time within a year & {$[\mathrm{h}]$} & 8600 \\
\hline $\begin{array}{l}\text { Aerodynamic surface roughness } \\
\text { coefficient }\end{array}$ & {$[\mathrm{m}]$} & 0.5 \\
\hline Waste gas temperature & {$[\mathrm{K}]$} & 400 \\
\hline Height of calculation net & {$[\mathrm{m}]$} & 0 \\
\hline
\end{tabular}

Table 2. Calculation parameters for individual cases

\begin{tabular}{|c|c|c|c|c|c|c|}
\hline Case & $\begin{array}{c}\text { Emitter height } \\
\mathrm{h}[\mathrm{m}]\end{array}$ & $\begin{array}{c}\text { Emitter internal } \\
\text { diameter } \\
\mathrm{d}[\mathrm{m}]\end{array}$ & $\begin{array}{c}\text { Number } \\
\text { of calculation points }\end{array}$ & $\begin{array}{c}\mathrm{PM} 10 \text { dust emission } \\
\mathrm{E}[\mathrm{kg} / \mathrm{h}]\end{array}$ & $\begin{array}{c}\text { Gas velocity at outlet } \\
\mathrm{v}[\mathrm{m} / \mathrm{s}]\end{array}$ & Fig. No. \\
\hline 1a. & 4 & 1 & 1201 & 0.09 & 5 & Fig. 2. \\
\hline 1b. & 10 & 1 & 2001 & 0.09 & 5 & Fig. 3. \\
\hline 2a. & 10 & 1 & 2112 & 1 & 5 & Fig. 4. \\
\hline 2b. & 50 & 1 & 2740 & 1 & 5 & Fig. 5. \\
\hline 3a. & 90 & 3 & 4366 & 30 & 10 & Fig. 6. \\
\hline 3b. & 110 & 3 & 5100 & 30 & 10 & Fig. 7. \\
\hline 4a. & 10 & 0.5 & 1972 & 0.09 & 5 & Fig. 8. \\
\hline 4b. & 10 & 1 & 4129 & 0.09 & 5 & Fig. 9. \\
\hline 5a. & 90 & 2 & 2560 & 30 & 10 & Fig. 10. \\
\hline 5b. & 90 & 3 & 4436 & 30 & 10 & Fig. 11. \\
\hline
\end{tabular}

Cases: $1,4-$ a single-family household; 2 - an industrial plant; $3,5-$ a thermal power plant 
an average industrial plant, for a variable height of $10 \mathrm{~m}$ and $50 \mathrm{~m}$.

In Figures 6 and 7, differences may be observed between the immission of pollution at various heights of the same emitter being a high thermal power plant emitter.

Figures 8 and 9 present a situation where the emitters in single-family households are $10 \mathrm{~m}$ high and have internal diameters of $0.5 \mathrm{~m}$ and $1 \mathrm{~m}$, respectively.

In Figures 10 and 11, the method of pollution dispersion in the air is visualised in the cases where 90-metre high emitters of parameters characteristic for thermal power plants have the internal diameters of $2 \mathrm{~m}$ and $3 \mathrm{~m}$, respectively.

\section{Analysis of results}

The performed calculations concerned the dispersion of PM10 dust in the atmosphere in the cases of varied geometric parameters of the emitters. The article presents two results for each case, characteristic for extreme cases (parameters).

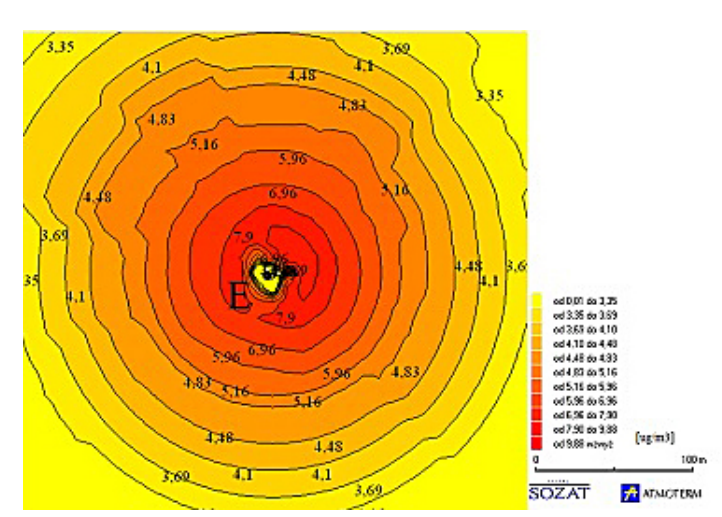

Figure 2. Isoline map of PM10 suspended dust concentration average for $1 \mathrm{~h}$, for $\mathrm{h}=4 \mathrm{~m}$

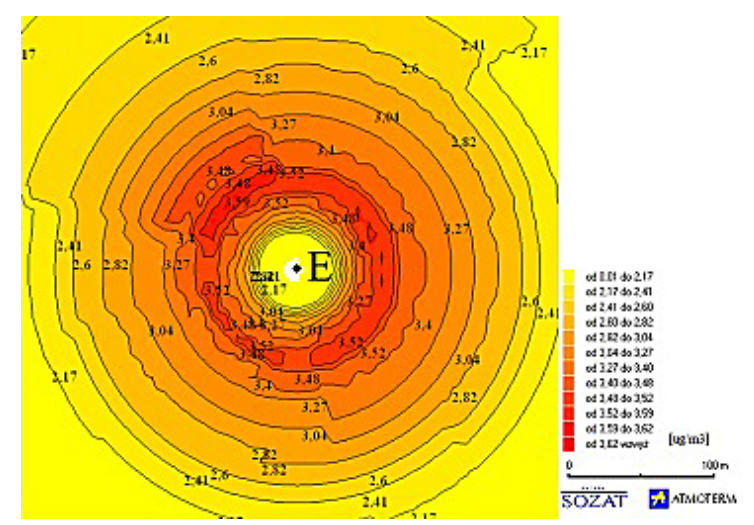

Figure 3. Isoline map of PM10 suspended dust concentration average for $1 \mathrm{~h}$, for $\mathrm{h}=10 \mathrm{~m}$
While analysing the influence of the geometric height of the emitter onto the immission of dust pollution (Fig. 2-7), it is easily noticeable that the higher the emitter, the lower the dust concentration in the atmosphere within the diameter 10 times larger than the height of the emitter. In the case of a single-family house where the chimney is $4 \mathrm{~m}$ high with an internal diameter of $1 \mathrm{~m}$ (Fig.2), the PM10 suspended dust falls onto the ground in the direct neighbourhood of the emitter. The maximum concentration occurs in the area of $12 \mathrm{~m}$ to $18 \mathrm{~m}$ from the building and reaches the values of approx. $10 \mu \mathrm{g} / \mathrm{m}^{3}$, after which they start decreasing, reaching the minimum value at the distance of about $100 \mathrm{~m}$ from the house. If the height of the emitter is increased to $10 \mathrm{~m}$, keeping the other parameters (Fig.3) stable, the so-called "silence zone", i.e. the area around the emitter where immission of the emitted pollution is not seen yet, is extended. The dust in the atmosphere appears at the level of the calculation net at a radius of approx. $26 \mathrm{~m}$ from the emitter. The area where the maximum calculated

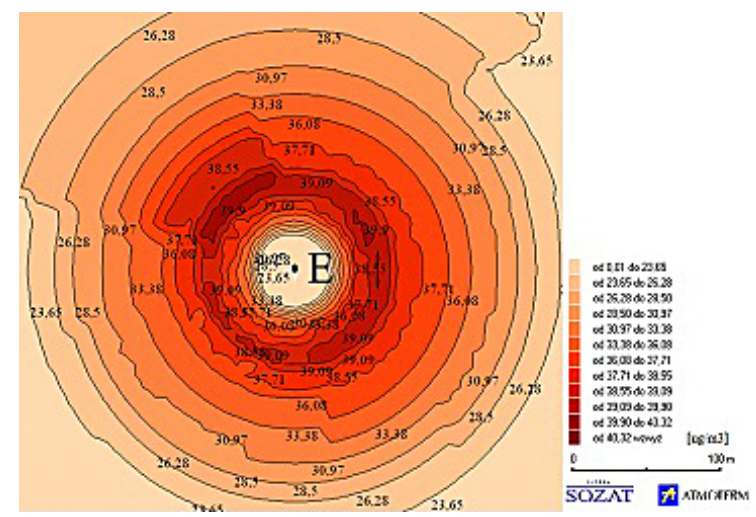

Figure 4. Isoline map of PM10 suspended dust concentration average for $1 \mathrm{~h}$, for $\mathrm{h}=10 \mathrm{~m}$

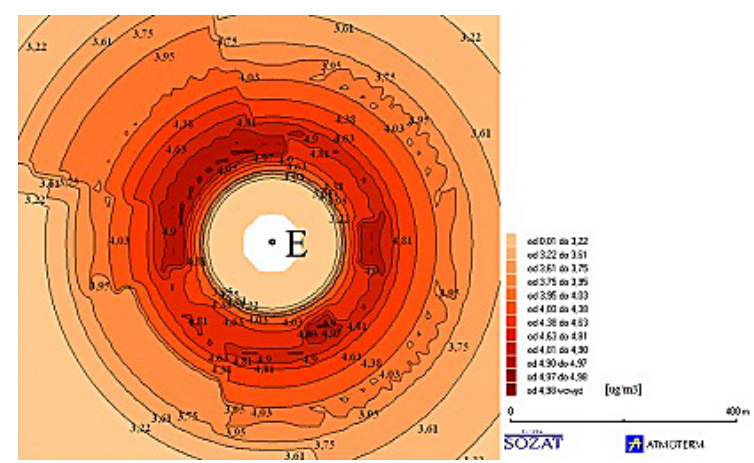

Figure 5. Isoline map of PM10 suspended dust concentration average for $1 \mathrm{~h}$, for $\mathrm{h}=50 \mathrm{~m}$ 


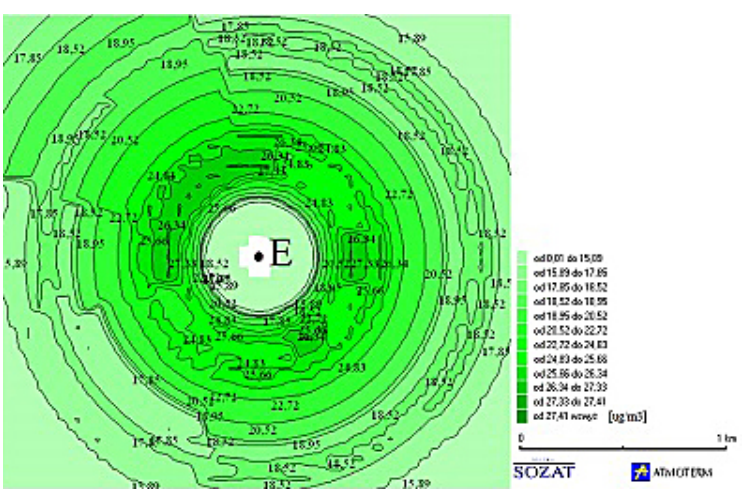

Figure 6. Isoline map of PM10 suspended dust concentration average for $1 \mathrm{~h}$, for $\mathrm{h}=90 \mathrm{~m}$

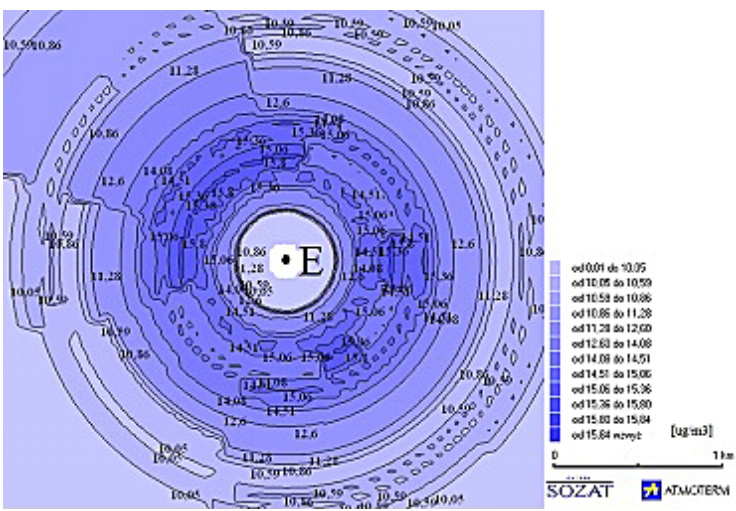

Figure 8. Isoline map of PM10 suspended dust concentration average for $1 \mathrm{~h}$, for $\mathrm{d}=1 \mathrm{~m}$

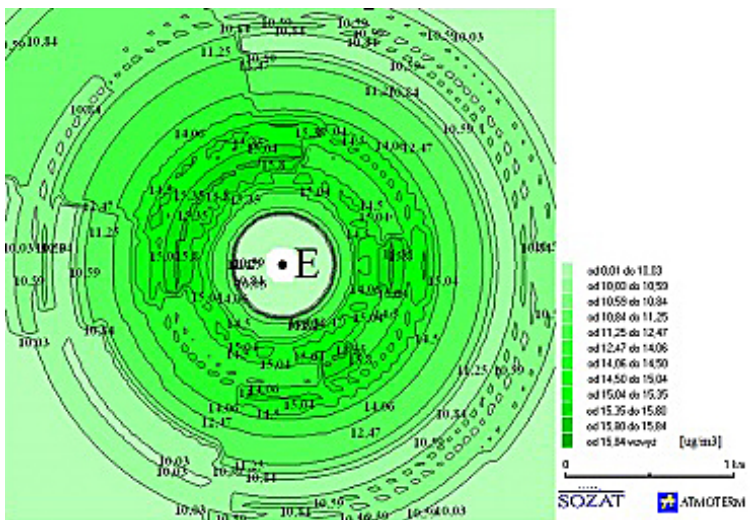

Figure 7. Isoline map of PM10 suspended dust concentration average for $1 \mathrm{~h}$, for $\mathrm{h}=110 \mathrm{~m}$

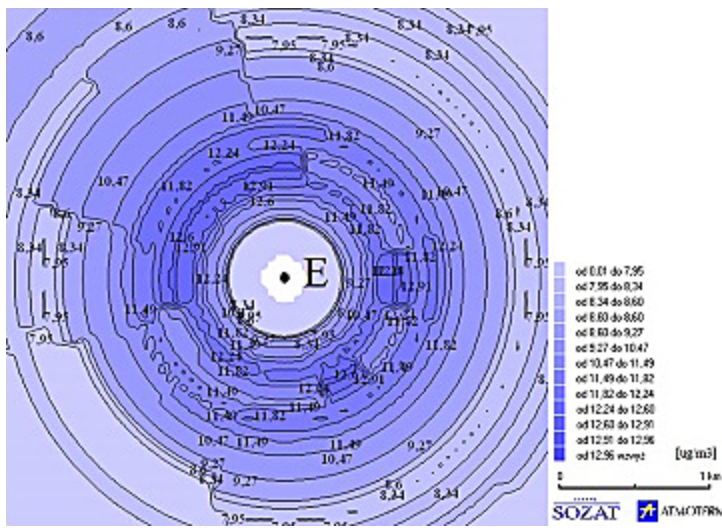

Figure 9. Isoline map of PM10 suspended dust concentration average for $1 \mathrm{~h}$, for $\mathrm{d}=0.5 \mathrm{~m}$

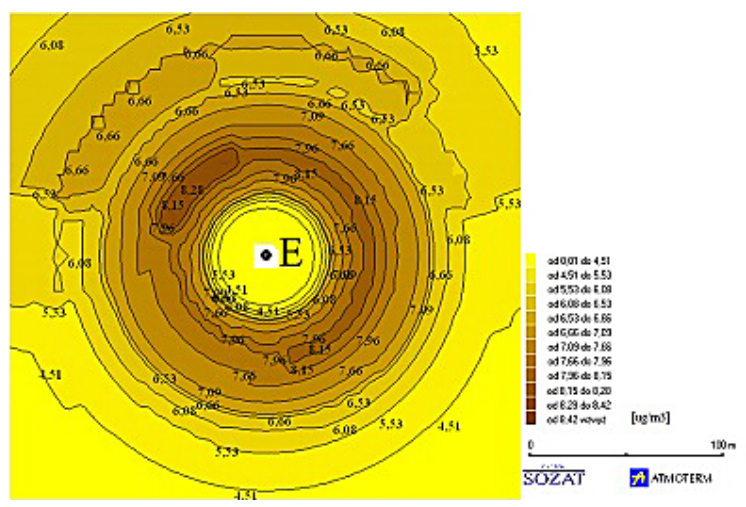

Figure 10. Isoline map of PM10 suspended dust concentration average for $1 \mathrm{~h}$, for $\mathrm{d}=2 \mathrm{~m}$

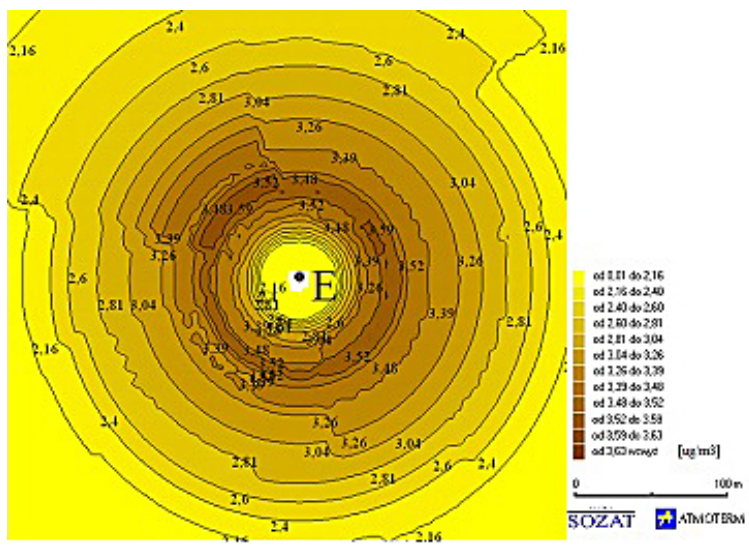

Figure 11. Isoline map of PM10 suspended dust concentration average for $1 \mathrm{~h}$, for $\mathrm{d}=3 \mathrm{~m}$ 
concentration is seen spans from $60 \mathrm{~m}$ to $70 \mathrm{~m}$ from the emitter, i.e. much further than in the case of a 4-metre-high emitter, and the values reach almost $4 \mu \mathrm{g} / \mathrm{m}^{3}$. What results from it is that if the height of a single-family house chimney is increased by 2.5 times, the maximum concentration which will occur in the area of the emitter will fall by $60 \%$ and the distance of its occurrence will be increased 5 times. The range of the emitter will increase but the immission of the dust will be lower in its total area.

While analysing the case of an emitter characteristic for an average industrial plant (Fig.4-5), modelling of the geometric height of the emitter was carried out, assuming its internal diameter of $1 \mathrm{~m}$ and the height of $10 \mathrm{~m}$ (Fig.4) and $50 \mathrm{~m}$ (Fig.5). In the first case, the silence zone is minimal and immission starts increasing relatively dynamically, reaching the values of approx. $23 \mu \mathrm{g} / \mathrm{m}^{3}$ already at the distance of about $20 \mathrm{~m}$ from the emission source. The maximum concentration is over $40 \mu \mathrm{g} / \mathrm{m}^{3}$ and spans in an area from about 60 to about $70 \mathrm{~m}$ from the emitter, after which is started to fall to the values of about $20 \mu \mathrm{g} / \mathrm{m}^{3}$ at the distance from about 175 to $210 \mathrm{~m}$. Due to the high immission and a large influence area of the emitter in the above-mentioned case, Fig. 4 does not depict the total range of the emitter's influence $(50 \mathrm{x} \mathrm{h})$. While analysing the dispersion of PM10 emitted from a 50-metre high emitter, which is depicted in the form of isolines of concentration in Fig.5, it can be observed that the silence zone extended to over $50 \mathrm{~m}$. When compared to the previous situation, here immission increases very slowly along with the distance from the point source of emission. Within the radius of approx. $112 \mathrm{~m}$, it reaches values of about $3.2 \mu \mathrm{g} / \mathrm{m}^{3}$. The maximum concentration is approx. $5 \mu \mathrm{g} / \mathrm{m}^{3}$ and is observed at the distance from 112 to $160 \mathrm{~m}$ from the emitter. Approximately $500 \mathrm{~m}$ from the point source of the emission, the concentration value is about $3 \mu \mathrm{g} / \mathrm{m}^{3}$. The comparison indicates that in the analysed case, after the geometric height of the industrial emitter is increased by 5 times with the other parameters unchanged, the maximum immission drops by almost $88 \%$. The distance of the highest concentration is increased by over $170 \%$.

While performing an analogical modelling in the case of a high emitter, characteristic for a thermal power plant, it was determined that with the height of $90 \mathrm{~m}$ and the internal diameter of $3 \mathrm{~m}$ (Fig.6), the radius within which no
PM10 suspended dust was recorded was $97 \mathrm{~m}$, while with the height of $110 \mathrm{~m}$ (Fig.7) it was up to $140 \mathrm{~m}$. In the first case, the immission at the distance of $290 \mathrm{~m}$ was at the level of $10 \mu \mathrm{g} / \mathrm{m}^{3}$, while in the second case, the concentration started rising dynamically at the distance of $350 \mathrm{~m}$, from the level of approx. $8 \mu \mathrm{g} / \mathrm{m}^{3}$. When the height of the emitter was $90 \mathrm{~m}$, the maximum immission occurred at a distance of over $480 \mathrm{~m}$, with the value of almost $16 \mu \mathrm{g} / \mathrm{m}^{3}$, while when the emitter's height was $110 \mathrm{~m}$, the maximum values of PM10 were approximately $13 \mu \mathrm{g} / \mathrm{m}^{3}$, and the distance of its occurrence varied from 600 to $700 \mathrm{~m}$ from the emission source. In the first case, the immission values returned to their lowest at a distance of $1.5 \mathrm{~km}$, while in the second case not closer than over $2 \mathrm{~km}$ from the emitter. Together with an increase of the emitter's height by 1.2 times, the maximum immission decreased by $18 \%$ and the distance of its occurrence increased by $26 \%$.

Another stage of modelling the geometric parameters of a point source/emitter involved performing calculations for various internal diameters of the emitters with the other technological and emission parameters unchanged. The calculations concerned various internal diameters characteristic for single-family households and the high emitters characteristic for thermal power plants. In Figures 8 and 9, the distribution of isolines was depicted for the PM10 concentration with the assumption that the emitter is $10 \mathrm{~m}$ high and the emission parameters are characteristic for an average household. Figure 8 depicts the dispersion of pollution emitted by an emitter with the internal diameter of $1 \mathrm{~m}$, while Figure 9 depicts an emitter with a diameter of $0.5 \mathrm{~m}$. In the first case, the silence zone was almost $7 \mathrm{~m}$, while in the second $-5 \mathrm{~m}$. At analogical distances from the emission source, the air pollution was higher in the case of the bigger diameter. Where the diameter was $1 \mathrm{~m}$, the maximum immission was approx. $8.4 \mu \mathrm{g} / \mathrm{m}^{3}$ and occurred at the distance of $47 \mathrm{~m}$ from the emitter, and for the diameter of $0.5 \mathrm{~m}$ the value was calculated at the level of $3.6 \mu \mathrm{g} / \mathrm{m}^{3}$, and not closer than $60 \mathrm{~m}$ from the emitter. Thus, it may be stated that - in the given case - when the diameter of the house point source/ emitter was decreased from $1 \mathrm{~m}$ to $0.5 \mathrm{~m}$, the maximum immission decreased by $57 \%$. The distance where the highest concentration occurred, increased by almost $30 \%$.

Figure 10 depicted how pollution is dispersed in the air in the case of the emission from a thermal 
power plant chimney stack with the height of $90 \mathrm{~m}$ and the internal diameter of $2 \mathrm{~m}$. The area where the emitter dust was not recorded spans to approx. $90 \mathrm{~m}$. Then, the concentration rose from $16 \mu \mathrm{g} / \mathrm{m}^{3}$ at the distance of about $260 \mathrm{~m}$, reaching the highest values of approx. $27 \mu \mathrm{g} / \mathrm{m}^{3}$ at the distance of about $390 \mathrm{~m}$ from the thermal power plant's emitter. After the increase of the diameter to $3 \mathrm{~m}$, the silence zone increased insignificantly to $94 \mathrm{~m}$. The maximum immission decreased to approx. $16 \mu \mathrm{g} / \mathrm{m}^{3}$, i.e. to the value which occurred in the first case at the lowest level, taking into account the concentration isolines. With the diameter of $2 \mathrm{~m}$, immission of approx. $16 \mu \mathrm{g} / \mathrm{m}^{3}$ occurred at the radius of about $260 \mathrm{~m}$, while with the diameter of $3 \mathrm{~m}$, not closer than at the distance of $625 \mathrm{~m}$ from the analysed emitter. The analysed case may thus be summarised with a statement that if the internal diameter of the thermal power plant emitter is increased from $2 \mathrm{~m}$ to $3 \mathrm{~m}$, i.e. by $50 \%$, the maximum immission will decrease by over $40 \%$ and the range of highest concentrations of PM10 will increase by almost $20 \%$.

The results of the analyses confirm that designing emission is an important aspect which involves the consequences of exposing people and the environment to high concentrations of pollution in the air if the emitters are not designed in a thoughtful way.

\section{CONCLUSIONS}

1. The maximum dust concentration in the air observed at the level of the calculation net is inversely proportional to the geometric height of the emitter, i.e. the concentration decreases with the increase of the emitter's height. In the case of an emitter of a single-family house, with an increase of the height by 2.5 times, the maximum immission decreases by $60 \%$. In the case of an industrial plant, when the height is increased 5 times, the highest concentration decreases by $88 \%$, and when the height of a thermal power plant emitter's height is increased by $22 \%$, the maximum concentration decreases by $18 \%$.

2. The area with the highest values of immission decreases when the emitter's height is increased. The distance for a single-family household emitter increased by $400 \%$, for an industrial plant by $170 \%$, and for a thermal power plant by $26 \%$.

3 . In the case of low emitters, characteristic for households, with the decrease of the internal diameter of the emitter by $100 \%$, the maximum immission is reduced by $57 \%$ and the distance of its occurrence increases by approx. $30 \%$.

4. In the case of high emitters, characteristic for thermal power plants, with the increase of the internal diameter of the emitter by $50 \%$, the maximum immission decreases by $42 \%$ and the distance of its occurrence increases by approx. $20 \%$.

\section{REFERENCES}

1. Janka R.M. 2014. Zanieczyszczenia pyłowe i gazowe, Podstawy obliczania i sterowania poziomem emisji. Warszawa: Wyd. Nauk. PWN.

2. Juda-Rezler K. 2000. Oddziaływanie zanieczyszczeń powietrza na środowisko, Oficyna Wydawnicza Politechniki Warszawskiej, Warszawa.

3. Ustawa z dnia 27 kwietnia 2001 r. Prawo ochrony środowiska. Dz. U. nr 62, poz. 627.

4. Markiewicz M.T. 2004. Podstawy modelowania rozprzestrzeniania się zanieczyszczeń w powietrzu atmosferycznym, Oficyna Wydawnicza Politechniki Warszawskiej, Warszawa.

5. Rozporządzenie Ministra Środowiska $\mathrm{z}$ dnia 26 stycznia 2010 r. w sprawie wartości odniesienia dla niektórych substancji w powietrzu.

6. Michalczyk J.K. 2003. Rozprawa doktorska, promotor: dr hab. Krzysztof Murawski, prof. UMCS, Transport gazowych zanieczyszczeń w powietrzu - symulacje numeryczne w skali lokalnej, Lublin.

7. Ek100w - Instrukcja Użytkownika 2007, Atmoterm, Opole.

8. Wierzbińska M. 2016. The effect of point emitter geometric parameters on dustfall. ChemistryDidactics-Ecology-Metrology. 21(1-2), 83-95. DOI: $10.1515 / \mathrm{cdem}-2016-0007$

9. Wierzbińska M. 2017. Modelowanie rozprzestrzeniania się zanieczyszczeń emitowanych z emitorów punktowych. Inżynieria Ekologiczna. 18(2), 199-209. DOI: 10.12912/23920629/68315

10. Wierzbińska M. 2017. Modelowanie parametrów geometrycznych oraz rozmieszczenia emitorów w terenie. Ekologia a budownictwo. Przegląd Budowlany, No. 10, 129-133. 